\title{
Research on Availability of Data Center UPS Power Supply System
}

\author{
Chai Yongcai, Li Changchun, Li Qun, Yao Jianqiang \\ Research Institute of Petroleum Exploration \& Development-Northwest (NWGI) PetroChina \\ Lanzhou, China \\ chaiyc@petrochina.com.cn, licc@petrochina.com.cn, liqun@petrochina.com.cn, yao_jq@petrochina.com.cn
}

\begin{abstract}
According to the requirements of national standard for data center infrastructure, the typical case study is used to analyze the architecture, advantages and disadvantages of the UPS dual-bus $2 \mathrm{~N}$ redundant power supply system widely used in large and medium-sized data centers and establish the power supply system availability model to calculate its availability in this paper, so as to analyze the factors affecting the reliability of the data center and the development history of the data center power supply system, and verify the availability of the revised National standard A-level data center "One way (N+1) UPS and one way mains" double bus redundant power supply in GB50174-2017 data center design specification, and analyze its advantages in usability and energy efficiency, investment, and application development prospects.
\end{abstract}

Keywords-data center, UPS, power system, redundancy, availability, energy saving

\section{INTRODUCTION}

With the rapid development of the Internet and information technology, more and more information assets are becoming more and more important, and information processing, exchange and storage have more and more reliability requirements for data centers supporting information business. There are many factors affecting the availability of data centers, including power supply and distribution, air conditioning, monitoring, security, planning and design, equipment selection, construction and installation, operation and maintenance, and other aspects of construction and operation. The power subsystem is the first in data center infrastructure. The important subsystem, the power supply is the support of the normal operation of all IT equipment in the data center, just like the human blood circulation system is of the same importance to human survival [1]. The failure rate of the power security system accounts for $72.2 \%$ of the data center failure rate. Therefore, the most important thing of the data center infrastructure is the reliability of the power supply system [2].

There has been the requirement of uninterrupted power supply since the use of computer. It has experienced DC power supply, flywheel energy storage generator power supply, UPS single power supply, UPS series redundant power supply, UPS parallel operation $(\mathrm{N}+1)$ redundant power supply, UPS dualbus $2 \mathrm{~N}$ or $2(\mathrm{~N}+1)$ redundant power supply, high-voltage DC double-bus $2 \mathrm{~N}$ or $2(\mathrm{~N}+1)$ redundant power supply, etc., with their availability improved successively. In current, most large and medium-sized data centers are powered by UPS dual-bus $2 \mathrm{~N}$ redundancy, and with high-voltage DC power gradually being used.

In 2015, the power consumption of China's data center reached 100 billion $\mathrm{kWh}$, accounting for $1.5 \%$ of the total electricity consumption in the society [3]. Saving energy and reducing consumption is an unavoidable topic.

Based on the requirements of the national standard for data center infrastructure, this paper analyzes the architecture, advantages and disadvantages, and availability of the data center UPS dual-bus $2 \mathrm{~N}$ redundant power supply system in a typical case study.

The area of IT equipment room in the data center studied in this paper is about $3600 \mathrm{~m}^{2}$, divided into 6 areas, and $1200 \mathrm{IT}$ equipment cabinets are deployed. The power supply and distribution system is divided into two areas.

\section{POWER SUPPLY SYSTEM DESIGN}

\section{A. Requirements for Data Center Power System}

The main standards on which data center design is based are GB50174 (Data Center Design Specification) [4][5] and ANSI/TIA-942 (Data Center Telecommunications Infrastructure Standard) [6][7]. GB50174 is based on the nature of the data center. The loss or impact of data loss or network interruption in economic or social, the data center is divided into three levels A, B, C, ANSI / TIA-942 is divided into four levels T1 $\sim \mathrm{T} 4$. The data center of this case is determined to be Class A of GB50174 according to the nature of the business, close to the T4 level of ANSI/TIA-942. There is no single point of failure, fault tolerance, and parallel maintenance is possible. A single unplanned event will not affect the normal operation of IT equipment in the data center [8]. The GB50174 A and ANSI/TIA-942 T4 data center power supply system requirements are shown in Table I.

Funded by China National Petroleum Corporation Data Center (F4) project. 
TABLE I. DATA CENTER POWER SySTEM REQUIREMENTS

\begin{tabular}{|c|c|c|c|c|}
\hline \multirow[t]{2}{*}{ Project } & GB50174-2008 & $\begin{array}{c}\text { GB50174- } \\
2017 \\
\end{array}$ & $\begin{array}{c}\text { TIA942- } \\
2005 \\
\end{array}$ & TIA942-2017 \\
\hline & Class $A$ & Class $A$ & Class T4 & Class T4 \\
\hline Power supply & $\begin{array}{c}\text { Both power } \\
\text { supplies should } \\
\text { not be damaged } \\
\text { at the same } \\
\text { time }\end{array}$ & $\begin{array}{c}\text { Dual power } \\
\text { supply }\end{array}$ & $\begin{array}{l}\text { Two } \\
\text { active } \\
\text { power }\end{array}$ & $\begin{array}{c}\text { Two power } \\
\text { supplies from } \\
\text { different } \\
\text { substations or } \\
\text { power plants }\end{array}$ \\
\hline Transformer & $\begin{array}{c}\mathrm{M}(1+1) \\
\text { redundancy } \\
(\mathrm{M}=1,2,3 \ldots)\end{array}$ & $2 \mathrm{~N}$ & $2 \mathrm{~N}$ & $2 \mathrm{~N}$ \\
\hline $\begin{array}{c}\text { Diesel } \\
\text { generators }\end{array}$ & $\begin{array}{l}\mathrm{N} \text { or }(\mathrm{N}+\mathrm{X}) \\
\text { redundancy } \\
(\mathrm{X}=1 \sim \mathrm{N})\end{array}$ & $\begin{array}{l}(\mathrm{N}+\mathrm{X}) \\
\text { redundancy } \\
(\mathrm{X}=1 \sim \\
\mathrm{N})\end{array}$ & $\mathrm{N}+1$ & $2 \mathrm{~N}$ \\
\hline $\begin{array}{l}\text { Diesel } \\
\text { generator } \\
\text { basic } \\
\text { capacity }\end{array}$ & $\begin{array}{c}\text { Basic capacity } \\
\text { of UPS, basic } \\
\text { capacity of air } \\
\text { conditioning } \\
\text { and } \\
\text { refrigeration } \\
\text { equipment, } \\
\text { emergency } \\
\text { lighting and } \\
\text { fire protection, } \\
\text { etc. }\end{array}$ & $\begin{array}{c}\text { Basic } \\
\text { capacity of } \\
\text { UPS, Air } \\
\text { conditioning } \\
\text { and } \\
\text { Refrigeration } \\
\text { equipment }\end{array}$ & $\begin{array}{l}\text { Whole } \\
\text { building } \\
\text { load }\end{array}$ & $\begin{array}{l}\text { Whole building } \\
\text { load }\end{array}$ \\
\hline $\begin{array}{c}\text { Diesel } \\
\text { generator } \\
\text { fuel storage }\end{array}$ & $72 \mathrm{~h}$ & $12 \mathrm{~h}$ oil & $96 \mathrm{~h}$ & $96 \mathrm{~h}$ \\
\hline \multirow{3}{*}{$\begin{array}{c}\text { UPS } \\
\text { configuration }\end{array}$} & \multirow{3}{*}{$\begin{array}{c}2 \mathrm{~N} \text { or } \mathrm{M}(\mathrm{N}+1) \\
\text { redundancy } \\
(\mathrm{M}=2,3,4 \ldots)\end{array}$} & $\begin{array}{c}2 \mathrm{~N} \text { or } \\
\mathrm{M}(\mathrm{N}+1) \\
(\mathrm{M}=2,3,4 \ldots)\end{array}$ & \multirow{3}{*}{$2 \mathrm{~N}$} & \multirow{3}{*}{$2 \mathrm{~N} / \mathrm{N}+\mathrm{N}$} \\
\hline & & $\begin{array}{c}\text { One way } \\
(\mathrm{N}+1) \text { UPS } \\
\text { and one way } \\
\text { electricity }\end{array}$ & & \\
\hline & & $\begin{array}{c}\text { Can be } 2 \mathrm{~N}, \\
\text { also can } \\
(\mathrm{N}+1)\end{array}$ & & \\
\hline $\begin{array}{l}\text { UPS battery } \\
\text { standby time }\end{array}$ & $\begin{array}{l}15 \mathrm{~min} \\
\text { When diesel } \\
\text { generator is } \\
\text { used as backup } \\
\text { power source }\end{array}$ & $\begin{array}{c}15 \mathrm{~min} \\
\text { When diesel } \\
\text { generator is } \\
\text { used as } \\
\text { backup } \\
\text { power source }\end{array}$ & $15 \mathrm{~min}$ & $10 \mathrm{~min}$ \\
\hline $\begin{array}{c}\text { Air } \\
\text { conditioning } \\
\text { system } \\
\text { distribution }\end{array}$ & $\begin{array}{l}\text { Dual power } \\
\text { supply (at least } \\
\text { one emergency } \\
\text { power source) } \\
\text { end switch }\end{array}$ & $\begin{array}{l}\text { Dual power } \\
\text { supply (at } \\
\text { least one } \\
\text { emergency } \\
\text { power } \\
\text { source) end } \\
\text { switch }\end{array}$ & $\begin{array}{l}\text { Multipath } \\
\text { power } \\
\text { supply }\end{array}$ & $\begin{array}{l}2 \mathrm{~N} / \mathrm{N}+\mathrm{N}, \\
\text { redundancy }\end{array}$ \\
\hline $\begin{array}{c}\text { Supply } \\
\text { voltage range } \\
\text { of IT } \\
\text { equipment } \\
\end{array}$ & $\begin{array}{c}220 / 380 \mathrm{~V} \\
\pm 3 \%\end{array}$ & $\begin{array}{c}220 / 380 \mathrm{~V} \\
+7 \% \sim- \\
10 \%\end{array}$ & $120 / 208 \mathrm{~V}$ & - \\
\hline $\begin{array}{l}\text { Steady state } \\
\text { frequency } \\
\text { offset range }\end{array}$ & $\pm 0.5 \mathrm{~Hz}$ & $\pm 0.5 \mathrm{~Hz}$ & - & - \\
\hline $\begin{array}{l}\text { Input voltage } \\
\text { waveform } \\
\text { distortion } \\
\end{array}$ & $\leq 5 \%$ & $\leq 5 \%$ & - & - \\
\hline $\begin{array}{c}\text { Allowable } \\
\text { duration of } \\
\text { power outage }\end{array}$ & $0 \sim 4 \mathrm{~ms}$ & $0 \sim 10 \mathrm{~ms}$ & - & - \\
\hline $\begin{array}{l}\text { Zero ground } \\
\text { voltage }\end{array}$ & $<2 \mathrm{~V}$ & - & - & - \\
\hline
\end{tabular}

\section{B. UPS power supply system design}

The data center $2 \mathrm{~N}$ dual-bus UPS power supply system block diagram is shown in Figure 1; Two-way $10 \mathrm{KV}$ mains supply comes from different substations, and single-way mains capacity meets data center power supply load requirements.;4 transformers and 4 backup diesel generators are connected to the 4-segment bus bar power distribution cabinet after putting into operation. 12 UPSs are divided into 6 groups (2 parallel units) to form 3 sets of $2 \mathrm{~N}$ redundant systems for IT load in 6 areas. There are 2 sets of (2 way) floor power distribution cabinets in each area; and 1 set of double-sided array cabinet is set in each row of cabinets. Each cabinet should be set with 2 ( 2 channels) multi-plug PDUs; and Cabinets with a singlesupply load (rarely used) should be set with a small ATS that can be quickly installed.

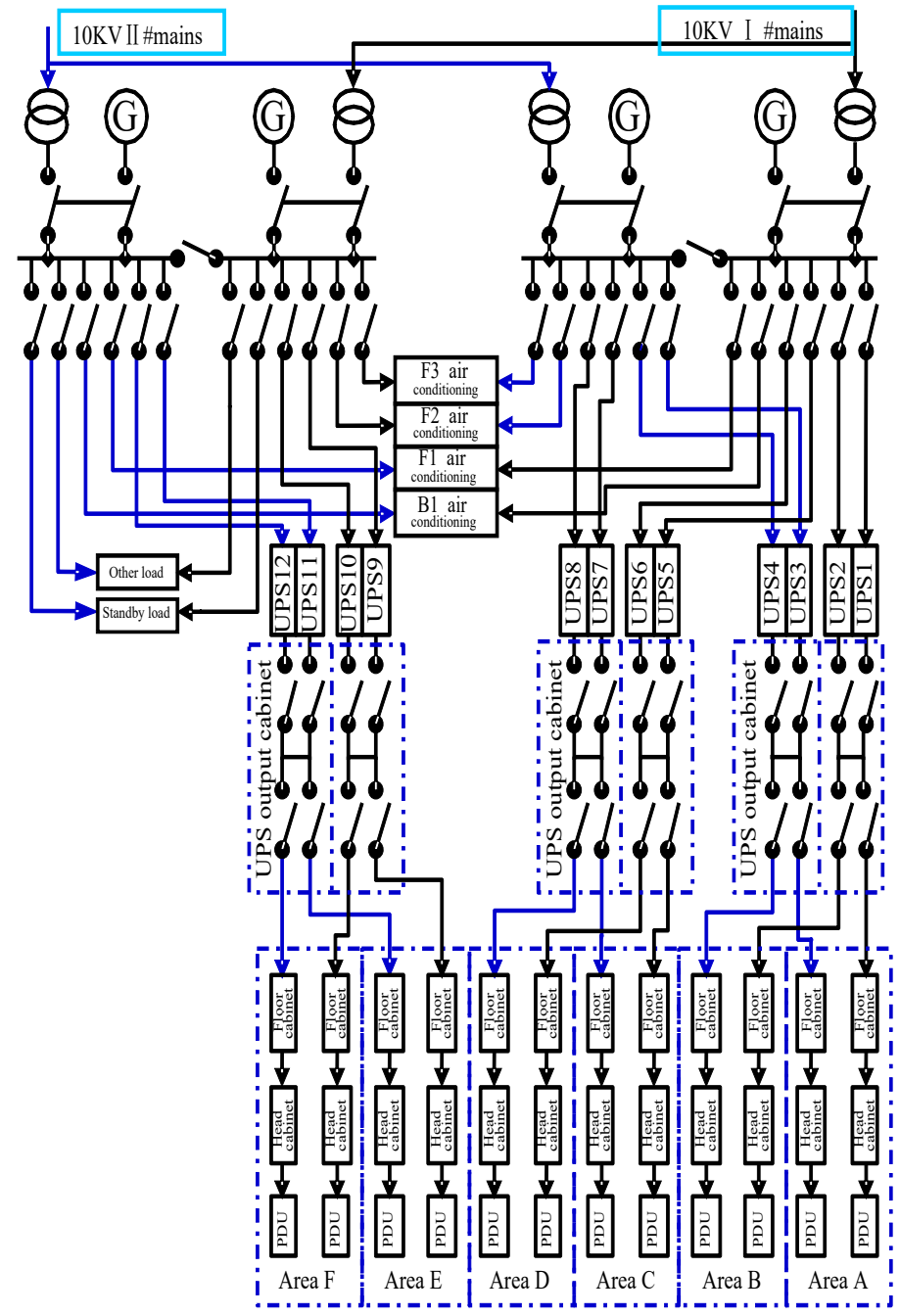

Fig. 1. Block Diagram of $2 \mathrm{~N}$ double bus UPS Power supply system

\section{CALCULATION OF AVAILABILITY}

\section{A. Availability data of power supply system}

Availability refers to the ratio of the time that the system can be used to the total time during use. It can be quantified by 
mean time between failures and mean time to repair [9], namely:

$$
\mathrm{A}=\mathrm{MTBF} /(\mathrm{MTBF}+\mathrm{MTTR})
$$

\section{Where: A - availability}

MTBF - mean time between failures

\section{MTTR - average repair time}

MTBF stands for the reliability of the system or component (link). The higher the MTBF, the higher the availability. The MTTR represents the maintainability of the system or component (link). The lower the MTTR, the higher the availability.

The data center power supply system consists of grid power, transformer, switchboard (cabinet), ATS, generator, UPS, PDU, battery, STS and other components. According to the longterm operation and maintenance statistics of professional institutions, media, manufacturers and users, the availability data of power supply system components (links) is shown in Table II[1].

TABLE II. AVAILABILITy DATA OF POWER SUPPly SYSTEM COMPONENTS

\begin{tabular}{|c|c|c|c|c|}
\hline NO & Component (link) & MTBF(h) & MTTR(h) & Availability A \\
\hline $\mathrm{A}_{1}$ & Grid Power & & & 0.99979779 \\
\hline $\mathrm{A}_{2}$ & transformer & 1484736 & 156 & 0.999894942 \\
\hline $\mathrm{A}_{3}$ & switchboard (cabinet) & 1011060 & 2.78 & 0.99999725 \\
\hline $\mathrm{A}_{4}$ & high power ATS & 102093.95 & 5.74 & 0.99994378 \\
\hline $\mathrm{A}_{5}$ & generator & 273298.7 & 18.58 & 0.99993202 \\
\hline $\mathrm{A}_{6}$ & UPS & 156362 & 8 & 0.999948839 \\
\hline $\mathrm{A}_{7}$ & PDU & 500000 & 1 & 0.999998 \\
\hline $\mathrm{A}_{8}$ & low power ATS & 500000 & 0.5 & 0.999999 \\
\hline $\mathrm{A}_{9}$ & UPS battery & 1402524 & 23.8 & 0.999983031 \\
\hline $\mathrm{A}_{10}$ & STS & 162022 & 7 & 0.999956798 \\
\hline
\end{tabular}

\section{B. Availability Model of UPS Power supply system}

After analysis of the $2 \mathrm{~N}$ dual-bus UPS power supply system shown in Figure 1, there are following five redundant relationships:

- The grid mains supply forms AC redundant input with the backup diesel generator set via transformer;

- Two-way AC redundancy input make redundant power supply for equipment such as air conditioners via ATS;

- Since the equipment load rate of the $2 \mathrm{~N}$ system is not more than $50 \%$, the two UPSs connected in parallel can be regarded as $1+1$ redundancy;

- Dual power supply load is redundantly supplied by 2 UPS power supplies;
- Single-supply load is redundantly powered by two UPS power supplies.

According to the above five redundancy relationships, the availability model of the $2 \mathrm{~N}$ dual-bus UPS power supply system can be seen in Figure 2 .

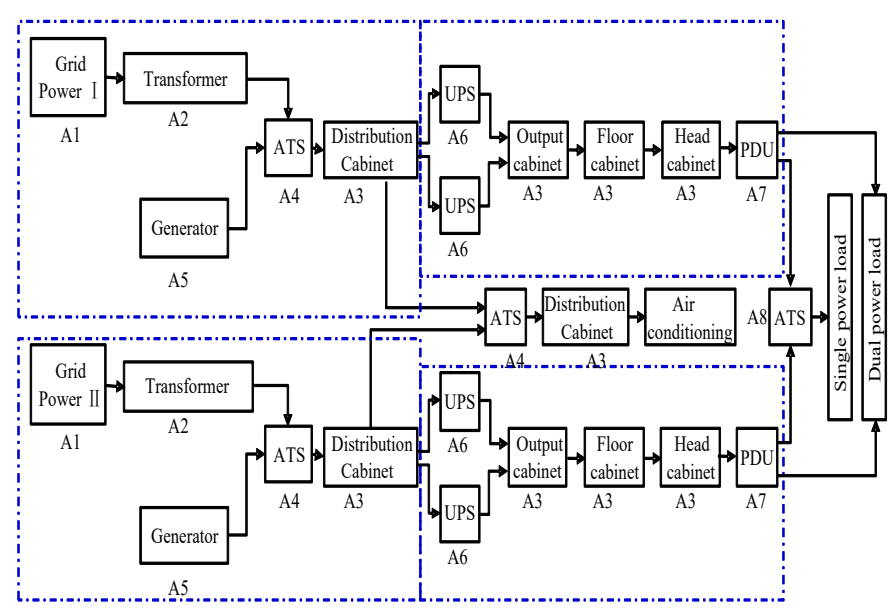

Fig. 2. Availability Model of $2 \mathrm{~N}$ dual bus UPS Power supply system

\section{Availability calculation of UPS Power system}

System availability can be calculated from the availability model of Figure 2 and the UPS power system component (link) availability data of Table 2 .

The availability of power supply between the grid mains and the diesel generators through the power distribution cabinet is indicated by the $A_{C}$.

$$
\begin{aligned}
\mathrm{A}_{\mathrm{C}} & =\left[1-\left(1-\mathrm{A}_{1} \times \mathrm{A}_{2}\right) \times\left(1-\mathrm{A}_{5}\right)\right] \times \mathrm{A}_{4} \times \mathrm{A}_{3} \\
& =0.9999410101
\end{aligned}
$$

After the two power sources are mutually invested, they are used by air conditioners and other devices, and their availability is represented by $A_{A}$.

$$
\begin{aligned}
\mathrm{A}_{\mathrm{A}} & =\left[1-\left(1-\mathrm{A}_{\mathrm{C}}\right) \times\left(1-\mathrm{A}_{\mathrm{C}}\right)\right] \times \mathrm{A}_{4} \times \mathrm{A}_{3} \\
& =\left[1-\left(1-\mathrm{A}_{\mathrm{C}}\right)^{2}\right] \times \mathrm{A}_{4} \times \mathrm{A}_{3} \\
& =0.9999410275
\end{aligned}
$$

The UPS output passes through the output cabinet and the head cabinet to the cabinet PDU, and its availability is represented by $A_{P}$.

$$
\begin{aligned}
A_{P} & =A_{C} \times\left[1-\left(1-A_{6}\right)^{2}\right] \times A_{3} \times A_{3} \times A_{3} \times A_{7} \\
& =0.9999307594
\end{aligned}
$$
by $A_{D}$.
The power availability of a dual-supply IT load is indicated 


$$
\begin{aligned}
A_{D} & =\left[1-\left(1-A_{P}\right)^{2}\right] \\
& =0.9999999952
\end{aligned}
$$

The power availability of a single-supply IT load is indicated by $A_{S}$.

$$
\begin{aligned}
\mathrm{A}_{\mathrm{S}} & =\left[1-\left(1-\mathrm{A}_{\mathrm{P}}\right)^{2}\right] \times \mathrm{A}_{8} \\
& =0.9999989952
\end{aligned}
$$

\section{Analysis of $2 \mathrm{~N}$ double busbar UPS power supply system}

- The $2 \mathrm{~N}$ dual-bus UPS power supply system has no single point of failure with fault tolerance, and can be used for parallel maintenance. A single unplanned event will not affect the operation of the data center IT equipment, and with high availability. According to the calculation result of equation (5), the power supply availability of the dual-supply IT load reaches 0.9999999952 , i.e. eight "9", which is much higher than the general availability of the T4 data center of 0.99995 [10].

- Despite the high availability of the $2 \mathrm{~N}$ dual-bus UPS power supply system, the overall availability of the data center is guaranteed by the availability of subsystems affecting the operation of the data center. The overall availability depends on the subsystem with the lowest availability among the subsystems, such as In this case, the power supply reliability of power equipment such as air conditioners is 0.99994 , which is slightly lower than the 0.99995 normally required by T4 data centers.

- In normal operation, the load rate of each device in the system is low, usually not more than $50 \%$.

- The system consumes a lot of energy.

- System investment is high.

- The $2 \mathrm{~N}$ dual bus UPS power supply system has achieved high availability. In some data centers, the $2(\mathrm{~N}+1)$ configuration for improving availability is not necessary. It only reduces the load rate of the device and increases system investment and energy consumption.

\section{AVAILABILITY OF ONE-WAY UPS AND ONE-WAY MAINS POWER SUPPLY SYSTEM}

\section{A. Model of availability of one-way UPS and one-way mains} power supply system

There are many ways to both ensure the availability of power supply systems and reduce the energy consumption and investment of power supply systems, such as high-voltage DC double-bus power supply; and A-level data center "One-way $(\mathrm{N}+1)$ UPS and one-way mains" double bus redundant power supply revised by GB50174-2017 GB is also a method that can ensure the availability of the power supply system while reducing system energy consumption and investment.
Remove 1 set of UPS and output cabinet in Figure 2, after the grid mains power supply is connected with backup diesel generator via transformer, it forms one way UPS and one way mains double bus power supply system through direct supply floor cabinet of distribution cabinet. The availability model is shown in Figure 3.

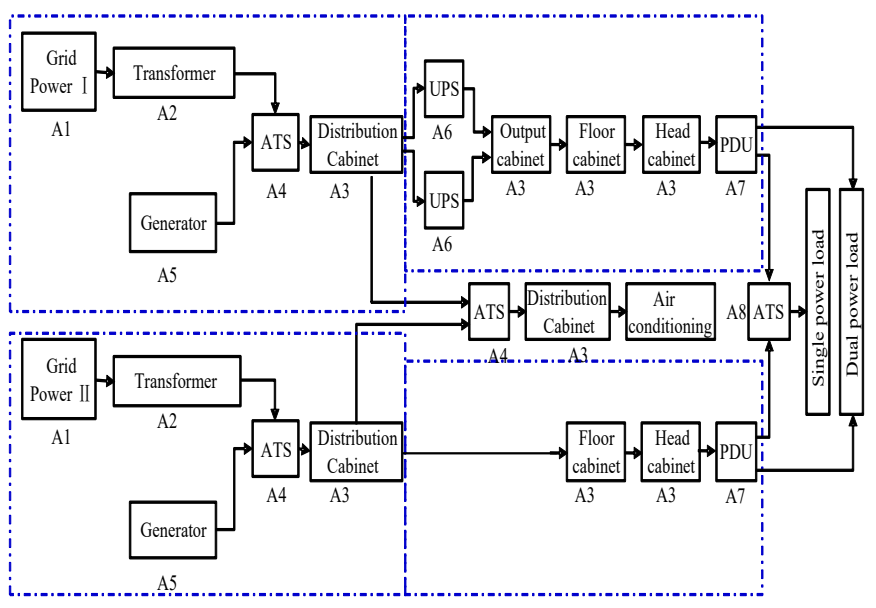

Fig. 3. Model of availability of one-way UPS and one-way mains power supply system

B. Availability calculation of one-way UPS power supply and one-way mains power supply system

The upper part of Figure 3 is consistent with Figure 2. The lower part omits the UPS and output cabinet links, and its PDU availability is indicated by $A_{P P}$.

$$
\begin{aligned}
A_{P P} & =A_{C} \times A_{3} \times A_{3} \times A_{7} \\
& =0.9999335114
\end{aligned}
$$

The power supply availability of the dual-supply IT load of the UPS and all-way mains double bus power supply system is indicated by $\mathrm{A}_{\mathrm{DD}}$.

$$
\begin{aligned}
\mathrm{A}_{\mathrm{DD}} & =\left[1-\left(1-\mathrm{A}_{\mathrm{P}}\right)\left(1-\mathrm{A}_{\mathrm{PP}}\right)\right] \\
& =0.9999999954
\end{aligned}
$$

The power supply availability of a single-supply IT load for one-way UPS and one-way mains double-bus power supply system is indicated by $\mathrm{A}_{\mathrm{SS}}$.

$$
\begin{aligned}
A_{S S} & =\left[1-\left(1-A_{P}\right)\left(1-A_{P P}\right)\right] \times A_{8} \\
& =0.9999989954
\end{aligned}
$$

\section{Analysis of one-way power and one-way UPS power system}

- One-way UPS and one-way mains double bus power supply system also have no single point of failure, which can be used for parallel maintenance. A single 
unplanned event does not affect the operation of IT equipment in the data center, and the availability is also high. From the previous calculation results, the power supply availability of the dual power supply load reached 0.999999954, which is 0.0000002 higher than the availability of the $2 \mathrm{~N}$ dual bus UPS power supply system of 0.999999952.

- The system consumes less energy. The loss of the six UPSs in Figure 1 can be reduced. In the figure, the UPS unit capacity is $400 \mathrm{KVA}$, the load rate is calculated at $45 \%$, and the UPS efficiency is calculated at $92 \%$. The annual electricity consumption can be 658,100 degrees. According to the Beijing industrial electricity price of $0.8 \mathrm{CNY} / \mathrm{kWh}$, the annual electricity saving can be $526,500 \mathrm{CNY}$.

- Low investment in systems. The investment in saving 6 UPS (including battery) and 3 output cabinets is about 5 million CNY. It can also save 6 UPS (including battery) and 3 output cabinets with an installation space of about $300 \mathrm{~m}^{2}$. According to the cost of $20,000 \mathrm{CNY} / \mathrm{m}^{2}$, it can save about 6 million CNY. The total investment can save 11 million $\mathrm{CNY}$.

- The power supply system equipment has a reduced failure rate, improved reliability, and reduced maintenance failure rate [11].

- In normal operation, the load rate of each device of the system is relatively low, usually less than $50 \%$.

- The UPS in Figure 2 is an N configuration, $N=2$. Since the equipment load rate of the dual bus power supply system is not more than $50 \%$, it is actually equivalent to $1+1$ redundancy and achieves high availability. GB50174-2017 newly revised national standard A-level data center "one way $(\mathrm{N}+1)$ UPS and one way mains" double bus redundant power supply mode $(\mathrm{N}+1)$ UPS configuration, when $\mathrm{N} \geqslant 2$ can be removed "+1 "When a single fault or single unplanned event occurs in the power supply system, it does not affect the operation of the IT equipment in the data center.

\section{CONCLUSION}

According to the requirements of national standard for data center infrastructure, the typical case study is used to analyze the architecture, advantages and disadvantages of data center UPS dual bus $2 \mathrm{~N}$ redundant power supply system and "one way $(\mathrm{N}+1)$ UPS and one way mains" dual bus redundant power supply system, to establish a power system availability model for calculating its availability. Although the most commonly used UPS dual-bus $2 \mathrm{~N}$ redundant power supply system is in high availability, it also has the disadvantages of high investment and high energy consumption. $2(\mathrm{~N}+1)$ UPS configuration is also unnecessary. The A-level data center "One-way $(\mathrm{N}+1)$ UPS and one-way mains" dual-bus redundant power supply mode revised by GB50174-2017 can remove " +1 " in case of $\mathrm{N} \geq 2$, which has great advantages in terms of usability, energy saving and investment that worth promoting due to its good application prospect.

\section{ACKNOWLEDGMENT}

The research was supported by the China National Petroleum Corporation Data Center (F4) project. Colleagues from the project team provided relevant experimental data and data center related operations, and thanked them again.

I would like to express my deep gratitude to the relevant data in the writing process. I would like to express my deep gratitude to Professor Zhang Guangming. His monograph "Component Usability Data" is very helpful for this research. Finally, I would like to thank my research team for their statistics on the research data and for correcting the chart.

\section{REFERENCES}

[1] Zhang Guangming, Chen Bing, Zhang Yanhe. Data Center Infrastructure Design and Construction [M]. Beijing: Electronics Industry Press, 2012.

[2] Wisdom Data Center Editorial Board. Smart Data Center [M]. Beijing: Electronics Industry Press, 2011.

[3] Dou Wenqing, Lei Wanyun, Jiang Yongkai. Modernization Technology and Practice of Enterprise Data Center [M]. Beijing: Tsinghua University Press, 2017.

[4] China Electronic Engineering Design Institute. GB50174-2008 Electronic Information System Computer Room Design Specification [S]. Beijing: China Planning Press, 2009.

[5] China Electronic Engineering Design Institute. GB50174-2017 Data Center Design Specification [S]. Beijing: China Planning Press, 2017.

[6] ANSI/TIA-942-2005 Telecommunications Infrastructure Standard for Data Centers[S]

[7] ANSI/TIA-942-B-2017 Telecommunications Infrastructure Standard for Data Centers[S]

[8] UPTIME INSTITUTE. Data Center Site Infrastructure Tier Standard: Topology-2018[S]

[9] Zhou Zhimin, Ji Aihua. Design and Fault Handling of UPS Power Supply System in Data Center [M]. Beijing: Electronics Industry Press, 2012.

[10] Lin Yusong, Li Runzhi, Liu Wei. Data Center Design and Management [M]. Beijing: Tsinghua University Press, 2017.

[11] Zhang Guangming et al. Several issues in data center infrastructure planning and design [M]. Beijing: Economic Science Press, 2015. 